\title{
Designing Educational Board Games For Children On Snake Handling Using Competitive Mechanisms
}

\author{
Josefin Oktaviane ${ }^{1 *}$, Jasson Prestiliano ${ }^{2}$, T. Arie Setiawan Prasida ${ }^{3}$ (iD \\ 1,2,3 Fakultas Teknologi Informasi Universitas Kristen Satya Wacana, Salatiga \\ *Corresponding author: josefinoktaviane@gmail.com
}

\begin{abstract}
Abstrak
Edukasi dengan materi dan hanya mendengarkan penjelasan membuat sebagian orang bosan sehingga informasi yang ingin disampaikan tidak diterima dengan baik. Selain itu kurangnya media yang dapat mengedukasi penanganan ular dan memfasilitasi anak dalam belajar dengan cara menyenangkan dan dapat dimainkan pada waktu luar diluar jam belajar. Penelitian ini bertujuan untuk menganalisis board game edukasi untuk penanganan ular menggunakan mekanisme competitive pada anak. Penelitian ini menggunakan metode deskriptif. Teknik yang digunakan dalam mengumpulkan data yaitu wawancara, observasi dan kuesioner. Instrument yang digunakan untuk mengumpulkan data adalah kuesioner. Sumber data yang didapat dari hasil penelitian terdahulu, artikel online dan hasil wawancara akan dianalisis secara deskriptif. Berdasarkan hasil analisis data, board game sebagai media edukasi tentang penanganan dasar terhadap ular berdampak positif bagi target. 80\% dari target yang tidak mengerti mengenai penanganan ular dan jenis-jenis ular menjadi paham dan menikmati edukasi yang diterapkan dalam media board game. Dapat disimpulkan bahwa board game edukasi dapat mengedukasi penanganan ular menggunakan mekanisme competitive pada anak.
\end{abstract}

Kata kunci: Board Game, Penanganan Ular

\section{Abstract}

Education with material and only listening to explanations make some people bored so that the information they want to convey is not well received. In addition, there is a lack of media that can educate snake handling and facilitate children in learning in a fun way and can be played outside of study hours. This study aims to analyze an educational board game for snake handling using competitive mechanisms in children. This research uses a descriptive method. The techniques used in collecting data are interviews, observations, and questionnaires. The instrument used to collect data is a questionnaire. Sources of data obtained from previous studies, online articles, and interviews will be analyzed descriptively. Based on the results of data analysis, the board game as an educational media about the basic handling of snakes has a positive impact on the target. $80 \%$ of the targets who do not understand handling snakes and other types of snakes understand and enjoy the education implemented in the board game media. It can be concluded that educational board games can educate children about snake handling using competitive mechanisms.

Keywords: Board Game, Handling, Snake

$\begin{array}{ll}\text { History: } & \text { Publisher: Undiksha Press } \\ \text { Received : January 19, } 2021 & \text { Licensed: This work is licensed under } \\ \text { Revised : March 03, } 2021 & \text { a Creative Commons Attribution 3.0 License } \\ \text { Accepted : April 04, } 2021 & \text { CC () O) } \\ \text { Published : April 25, 2021 } & \end{array}$

\section{Introduction}

Snakes are living creatures of the reptile species that are often considered terrible, dangerous animals. In the end, they cause fear so that they reflexively avoid the animal. As fellow living beings who the Creator gave life, they should live in peace with each other. Snakes are divided into venom and those without venom (Negara et all, 2018; Niasari \& Latief, 2016). Bad prejudices and myths about snakes make people unconsciously make snakes a hated and feared animal so that it often ends in the slaughter of snakes. At the same time, snakes have an important role in the food chain in the environment, such as controlling the number of rats or pests on crops or agricultural land not to grow rapidly. Today, many snakes are hunted for their skins and then sold and accidentally killed by humans on the grounds of self-defense. But what happened was that snakes were afraid of humans (Asri \& Yanuwiadi, 2015; Nainggolan, Kusrini, \& Kartono, 2017). From this situation, to prevent a decrease in snake habitat, education is needed for the community, starting from the children and inviting parents who accompany their children to study with their children. Education 
with materials and just listening to people talk can bore some people (Puspitorini, Subali, \& Jumadi, 2014; Yusnia, 2019). So we need media that can educate people but in a fun way and can be played in spare time or outside of study hours (Gunawan et al, 2017; Sunismi, 2015). One of the media that can be used is board games or board games.

The game is a recreational activity to fill free time when there is no work, improve mood, or do light exercise (Safitri, Primiani, \& Hartini, 2018; Suyeni, Wirya, \& Ujianti, 2016). Games are usually played alone or together. The board game is a game or game in which there are rules for how to play which is equipped with several components such as tokens, pawns that can be moved on a special board (Laily, Jalal, \& Karnadi, 2019; Triastuti, Akbar, \& Irawan, 2017). Examples such as chess, monopoly, and other board games In board games, several game mechanisms are used. One of the board game mechanisms is the competitive board game. Competition is a mechanic that invites players to fight for the same goal to win, and the player with the most points wins the game (ESun et al., 2015; Pratama, Wardani, \& Akbar, 2018). This competitive mechanism can attract the public. In dealing with various cases regarding the community's response to snakes, some people are afraid to see real photos of snakes commonly found in books and pictures. So in this board game, the snake as the main object will be depicted with a cartoon model that packs it in various colorings and still shows the original snake shape. Attractive media packaging will make it easier for respondents to capture the information presented (Mediatati \& Suryaningsih, 2017; Munandar, Sutrio, \& Taufik, 2018). In addition, the use of this media can create a comfortable and relaxed situation so that the information will be easy to remember.

Research conducted by Amanda (2019) stated that board game media could make children understand the importance of protecting orangutans. The similarity with this research is that the written problem is solved by the board game design method as an educational media. The difference with this research is the mechanism used and the problem raised as a research topic, the importance of protecting orangutans. Meanwhile, in this study, the problem lies in handling inappropriate snakes and still believing in myths. Research conducted by Safitri (2020) stated that the board game media could make it easier for students to understand the subject matter to improve students' problem-solving abilities. Based on the explanation above, this study aims to analyze an educational board game for snake handling using competitive mechanisms in children. This media is expected to help the public better understand how to distinguish and handle snakes that are venomous and nonvenomous using competitive mechanisms to make learning more interactive and interesting.

\section{Methods}

This study used a descriptive method, the development of the system used in this study was a linear strategy method. The techniques used in collecting data are interviews, observations, and questionnaires. The instrument used to collect data is a questionnaire. Sources of data obtained from previous studies, online articles, and interviews will be analyzed descriptively. The stages used in this study can be seen in Figure 1.

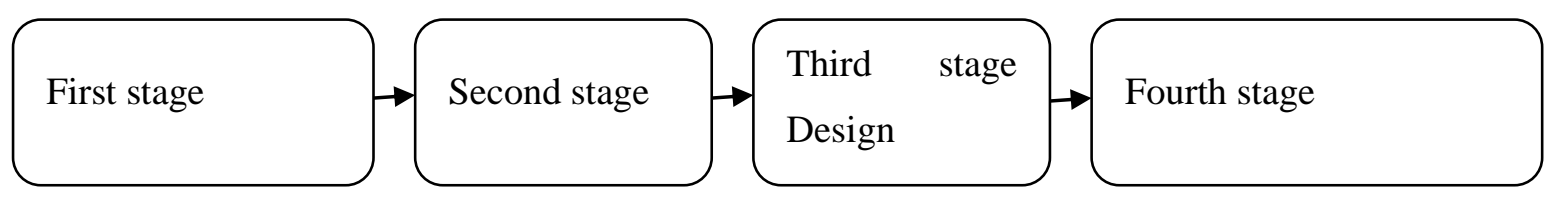

Figure 1. Research Stages

The first stage in this research was collecting data. This stage was done by reading books, journals, or previous research with discussion or media for the same solution. At this stage, interviews were conducted with members of Snake Rescue in Salatiga, residents in 
Salatiga who often encounter snakes in residential areas, and students who are still in elementary school. It aimed to determine the respondent's understanding in distinguishing which snakes are dangerous and which are not, how afraid people are of snakes, certain reasons for their fear of snakes, and how to handle snakes nearby. After the interview, observations were made to determine the techniques and appearance of the competitive type of board game. The competition was meant for Snake Rescue, who was training to handle snakes of different types. Not all types of snakes were used in this board game, but they are often found in Salatiga.

The second stage was data analysis and data management. The data will be removed from the data in the previous stage. The important data will be used in this study. The third stage was the design. The data that had been processed and analyzed will form a board game design concept to reduce the public's bad view of snakes in Salatiga using a competitive mechanism. After the concept had been obtained, the next step was making a prototype. The steps for making board games are based on the board game design process created by Eko Nugroho, CEO of Kummara; a company engaged in games that have Game Consultants, game developers, and publishers (Elianta, Prestiliano, \& Setiawan, 2018). The game design process consists of the Concepting Phase, Design Phase, and Development Phase, as shown in Figure 2.

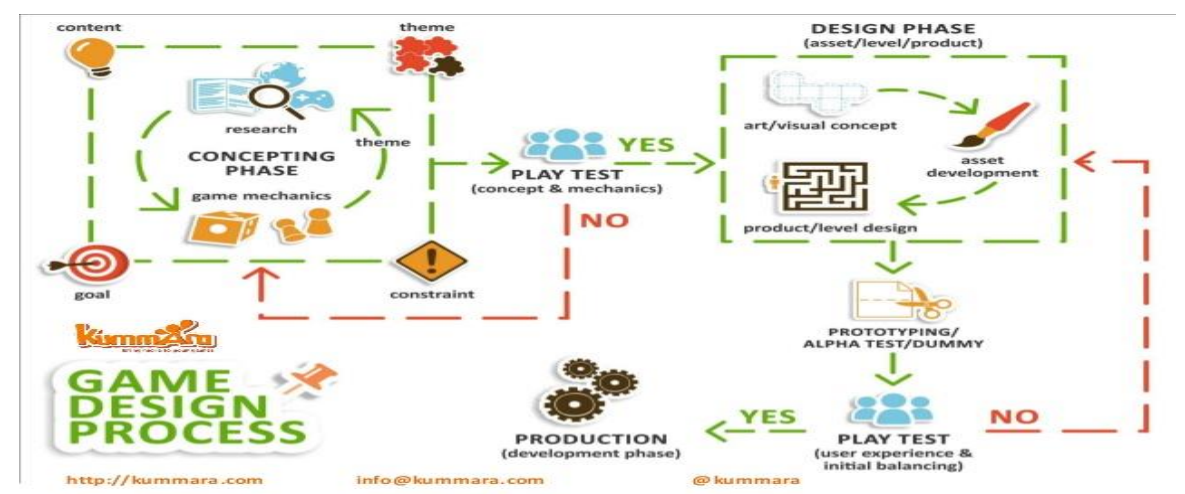

Figure 2. Game Design Process (Elianta et al., 2018)

After the design stage was complete and the board game seems feasible and ready to be tested, next to the stage of testing the target audience. The approach will be carried out qualitatively by interviewing children aged nine years who were the target audience who had tried the board game. Approaches will also be made with interviewed parents regarding the results of information media on how to distinguish and handle snakes. This data collection was carried out to create a board game concept for information media about snakes and handle them. The data obtained using qualitative and quantitative collection methods. Qualitative data collection was obtained from interviews with Widhi, as the representative of Snake Rescue in Salatiga. At the same time, quantitative data collection was obtained from questionnaires distributed in a group on social media that often discussed snakes.

\section{Results and Discussion}

The previously designed Board Game will contain information and materials on common snake-handling methods and are suitable for elementary school children to play. The basic way of handling snakes was to recognize the shape and color of the snake itself. Therefore, the snake card was added with a simple illustration, but the snake's characteristics can be recognized. The snake card contained ten types of snakes and their respective sizes and also used the snake expression to draw whether the snake was dangerous or not. Then 
behind the snake card, there was information on what to do when meeting the snake, from top to bottom, which was the last option that can be done when facing a snake. The snake card can be seen in Figure 4.

The action card contained useful items for dealing with snakes, divided into three categories: killer, catcher, repellent, and letting the snake do nothing to the snake. The theme of this board game was towards nature, so the basic color used was green. Also, green was the color of most places where snakes usually live, grass and plants. The color for the action category icon uses red for the killer item because it represents danger, and killing a snake should only be done when urgent. The catch item wears yellow because the yellow color depicts caution. After all, the catch needs to approach the snake carefully so that things do not happen that are not desirable. The last category was the repellent category that wears blue because this action can be done from a distance and prevent snakes from entering the human territory. Some of the action cards can be seen in Figure 5.
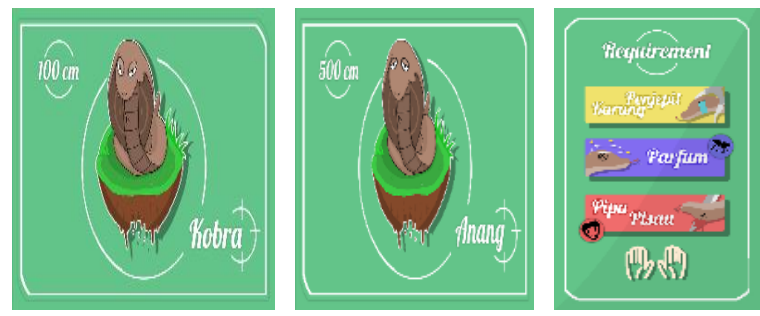

Figure 4. Snake Card.
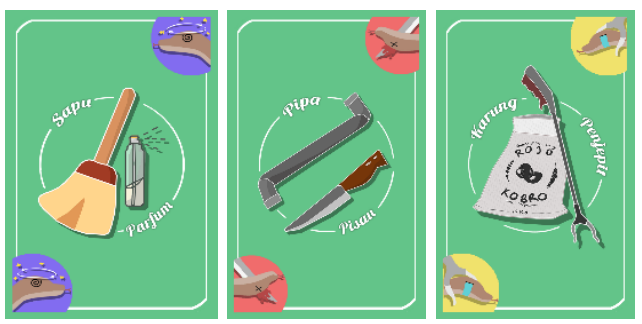

Figure 5. Action Card.

The event card only contains the writing of situations that usually occur when the handling process was carried out. Events that occurred with their descriptions use different colors of writing so that they can be distinguished. A circle in the red background also distinguished aggressive snakes and passive snakes to illustrate the danger of a snake in aggressive mode. A passive mode or a snake that was sleeping is depicted in blue. Some event cards can be seen in Figure 6. Components of the board game "Catch the Kobros!" consists of 20 snake cards, 28 action cards, 16 event cards. Components of the board game "Catch the Kobros!" can be seen in Figure 7.

The font used was Lobster. Lobster fonts were categorized in the script font group. This font was suitable for snake-themed board games because the physical shape of the snake resembles the font itself, it was still easy to read, and there was also a natural impression on this font. Lobster font can be seen in Figure 8.The Lobster font was used in the title "Catch the Kobros!" and edited. Edits made include adjusting the curve of the font so that it can bend and use shadows. The Lobster font applied to the board game title can be seen in Figure 9.

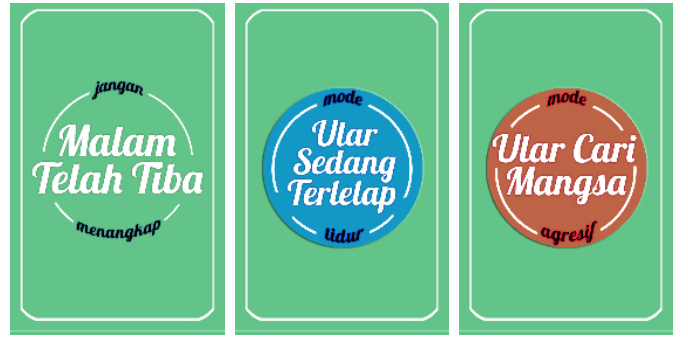

Figure 6. Event Card.

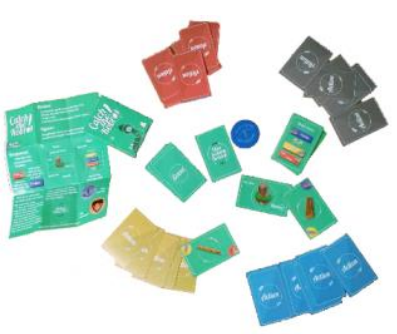

Figure 7. Catch the Kobros components! 


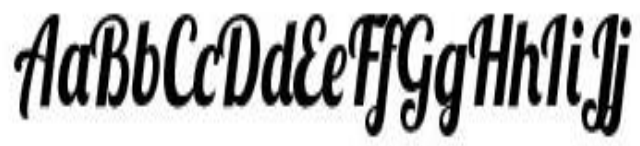

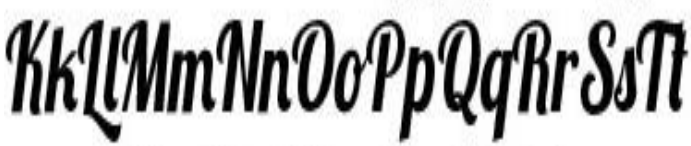 VulvWWuxxylyz

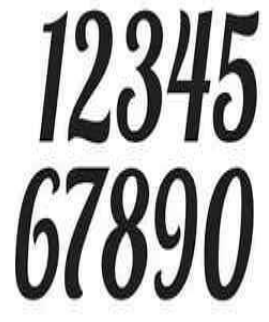

Figure 8. Font Lobster 1.4.
Figure 8. Font application for board game titles.

The first test was carried out on game design experts from Hompimpa Games before finally being tested on the target audience. Interviews were conducted with game design experts from Hompimpa Games. The interviews found that the board game Catch the Kobros was interesting and suitable for elementary school children to play. The purpose and information of the board game have been conveyed well, the way to play and the flow of the board game was easy to understand and suitable for the target audience but is not suitable when played by adults such as students, because the gameplay is too fast. The information written on the card is clear and easy to understand and includes a simple board game. After testing with game design experts, "Catch the Kobros!" ready to be tested on the target respondent, 30 students of SD Kalam Kudus Surakarta. The test was carried out in the respondent's house or a quiet public place due to the ongoing pandemic. Testing cannot be done in the classroom. The questionnaire used a Likert Scale to determine the percentage of the target respondent's opinion on "Catch the Kobros!"

Based on the results of data analysis obtained through questionnaires, $85 \%$ of respondents thought that the guide on how to play was easy to understand. As many as $90 \%$ of respondents thought that the game's setup or initial preparation was easy to understand and included fast to prepare. As many as $81.3 \%$ of respondents thought that the design of the board game card "Catch the Kobros!" was quite interesting, and $81.5 \%$ of respondents said that the illustration from "Catch the Kobros!" already quite interesting. As many as $87.5 \%$ of respondents agreed that there was the interaction between players during gameplay. Also, $86.6 \%$ of respondents thought that the game was fun, as evidenced by the enthusiasm of respondents to play the board game "Catch the Kobros!". As many as $85 \%$ of respondents agreed that the material and purpose of the board game had been conveyed well, and it was proven that $86 \%$ of respondents knew the types of snakes, and $85.8 \%$ of respondents agreed that respondents understood the basic ways of handling snakes. Seeing the respondents' enthusiasm, $84.1 \%$ of respondents wanted to play the board game "Catch the Kobros!" again, and $85.8 \%$ of respondents wanted to play "Catch the Kobros!" along with other friends.

The interviews with several parents of the target respondents for the board game "Catch the Kobros!" quite positive in responding to enthusiastic children, becoming more aware of basic snake-handling information, reducing fear when facing snakes because they already know what to do if they find a snake accidentally. As a parent, the material handling basic snakes in the game was easy to understand, and agreed that the board game "Catch the Kobros!" was used as a media of learning at school or home. Based on the results above, the research on board games as an educational media on basic snake-handling positively impacts the target. $80 \%$ of the targets do not understand or do not know about handling snakes and other types of snakes after playing "Catch the Kobros!". It can be concluded that board game media can help respondents understand the handling of snakes and types of snakes, several factors as follows. 
First, the board game media can help respondents understand the handling of snakes and other types of snakes because this media is interactive to understand better the material presented in the media. Appropriate learning media can convey messages well and stimulate one's mind (Gunawan et al., 2017; Qumillaila, Susanti, \& Zulfiani, 2017). Good learning media will encourage the creation of a good learning process in a person. Interesting learning media can also arouse someone's interest in learning (Arianti, Wiarta, \& Darsana, 2019; Rosidah, 2016). However, if the media was monotonous, the message to be conveyed will not be delivered optimally. Attractive media packaging will make it easier for respondents to capture the information presented (Mediatati \& Suryaningsih, 2017; Munandar et al., 2018). In addition, the use of this media can create a comfortable and relaxed situation so that the information will be easy to remember.

Second, board game media can help respondents understand snakes and other types of snakes because this media is interesting to increase respondents' interest in learning. The board game "Catch the Kobros!" was an interactive and interesting educational media so that it can be a solution to problems and people's lack of understanding of snake handling. Interactive learning media will make it easier for someone to understand the subject matter (Irwandani et al, 2017; Istiqlal, 2017; Yuniarni, Sari, \& Atiq, 2020). Children with parental supervision can use this board game to add insight into their nature for general educational purposes. The board game media is easier and more interesting in conveying the existing information because of the nature of the board game, which tends to be interactive and requires more than two people to exchange information. Board games with competitive mechanisms will invite the public to understand how to handle snakes properly and improve the public's bad view of snakes that have been feared and hated.

Research conducted by Elianta et al. (2018) stated that the board game learning media could make it easier for students to understand driving south. Research conducted by Safitri (2020) stated that the board game learning media is very practical and gets a positive response from students to improve students' problem-solving abilities. It can be concluded that board game media can be used as a means of education to channel information about snake handling properly. This research implies that the selection of the right educational media can help respondents understand the information well. Educational media in the form of board games can be used to educate snake handling to preserve snakes.

\section{Conclusion}

Based on the results of data analysis, the board game as an educational media about the basic handling of snakes has a positive impact on the target. It can be concluded that board game educational media can help respondents understand the basic handling of snakes.

\section{References}

Amanda, F. (2019). Perancangan Board Game sebagai Media Edukasi Pentingnya Melindungi Orangutan untuk Anak Usia 6-10 Tahun. In Adiwarna: Jurnal Desain Komunikasi Visual, 1(4). Retrieved from http://publication.petra.ac.id/index.php/dkv/article/view/8665.

Arianti, Wiarta, \& Darsana. (2019). Pengaruh Model Pembelajaran Problem Posing Berbantuan Media Semi Konkret terhadap Kompetensi Pengetahuan Matematika. Jurnal Ilmiah Sekolah Dasar, 3(4). https://doi.org/https://doi.org/10.23887/jisd.v3i4.21765.

Asri, A. S. K., \& Yanuwiadi, B. (2015). Persepsi Masyarakat Terhadap Ular sebagai Upaya Konservasi Satwa Liar Pada Masyarakat Dusun Kopendukuh, Desa Grogol, Kecamatan Giri, Kabupaten Banyuwangi. Jurnal Pembangunan Dan Alam Lestari, 
6(1). Retrieved from https://jpal.ub.ac.id/index.php/jpal/article/view/176.

Elianta, P., Prestiliano, J., \& Setiawan, T. A. (2018). Perancangan Board Game sebagai Media Pembelajaran Keselamatan Berkendara untuk Remaja dengan Mekanik Dice Rolling. International Journal of Natural Science and Engineering, 2(3). https://doi.org/http://dx.doi.org/10.23887/ijnse.v2i3.17186.

ESun, Z., EBai, T., EYu, W., EZhou, J., EZhang, M., \& EShen, M. (2015). Attentional bias in competitive situations: Winner does not take all. Frontiers In Psychology, 6(1). https://doi.org/https://doi.org/10.3389/fpsyg.2015.01469.

Gunawan, G., Sahidu, H., Harjono, A., \& Suranti, N. M. Y. (2017). The effect of project based learning with virtual media assistance on student's creativity in physics. Jurnal Cakrawala Pendidikan, 1(2). https://doi.org/https://doi.org/10.21831/cp.v36i2.13514.

Irwandani, Latifah, Asyhari, Muzannur, \& Widayanti. (2017). Modul Digital Interaktif Berbasis Articulate Studio'13: Pengembangan Pada Materi Gerak Melingkar Kelas X. Jurnal Ilmiah Pendidikan Fisika Al-BiRuNi, 6(2). https://doi.org/10.24042/jipfalbiruni.v6i2.1862.

Istiqlal, M. (2017). Pengembangan Multimedia Interaktif dalam Pembelajaran Matematika. Jurnal Ilmiah Pendidikan Matematika, 2(2), 43-3. https://doi.org/https://doi.org/10.26877/jipmat.v2i1.1480.

Laily, A., Jalal, F., \& Karnadi, K. (2019). Peningkatan Kemampuan Konsep Matematika Awal Anak Usia 4-5 Tahun melalui Media Papan Semat. Jurnal Obsesi, 3(2). https://doi.org/https://doi.org/10.31004/obsesi.v3i2.214.

Mediatati, N., \& Suryaningsih, I. (2017). Penggunaan Model Pembelajaran Course Review Horay Dengan Media Flipchart Sebagai Upaya Meningkatkan Hasil Belajar PKn. Jurnal Ilmiah Sekolah Dasar, I(2). https://doi.org/http://dx.doi.org/10.23887/jisd.v1i2.10146.

Munandar, H., Sutrio, S., \& Taufik, M. (2018). Pengaruh Model Pembelajaran Berbasis Masalah Berbantuan Media Animasi Terhadap Kemampuan Berpikir Kritis dan Hasil Belajar Fisika Siswa SMAN 5 Mataram Tahun Ajaran 2016/2017. Jurnal Pendidikan Fisika Dan Teknologi, 4(1), 111-120. https://doi.org/http://dx.doi.org/10.29303/jpft.v4i1.526.

Nainggolan, K., Kusrini, M. D., \& Kartono, A. P. (2017). Karakteristik Ular Sanca Batik (Python Reticulatus) Yang Dipanen Di Sumatera Utara. Jurnal Penelitian Hutan Dan Konservasi Alam, 4(1). https://doi.org/https://doi.org/10.20886/jphka.2017.14.1.4555.

Negara, I. N. W., Putriningsih, P. A. S., Arjentinia, I. P. G. Y., \& Prabawa, I. M. A. (2018). Fungi--fungi Penginfeksi Kulit Ular Liar di Bali. Indonesia Medicus Veterinus, 7(5). Retrieved from https://ojs.unud.ac.id/index.php/imv/article/view/43173/26200.

Niasari, N., \& Latief, A. (2016). Gigitan Ular Berbisa. Sari Pediatri, 5(3). https://doi.org/https://doi.org/10.14238/sp5.3.2003.92-8.

Pratama, D., Wardani, W. G. W., \& Akbar, T. (2018). The Visual Elements Strength in Visual Novel Game Development as the Main Appeal. MUDRA: Jurnal Seni Budaya, 3(3). https://doi.org/https://doi.org/10.31091/mudra.v33i3.455.

Puspitorini, Subali, \& Jumadi. (2014). Penggunaan Media Komik Dalam Pembelajaran IPA Untuk Meningkatkan Motivasi Dan Hasil Belajar Kognitif Dan Afektif. Cakrawala Pendidikan, 33(3), 413-420. Retrieved from https://journal.uny.ac.id/index.php/cp/article/view/2385/pdf.

Qumillaila, Susanti, \& Zulfiani. (2017). Pengembangan Augmented Reality Versi Android Sebagai Media Pembelajaran Sistem Ekskresi Manusia. Cakrawala Pendidikan, 34(1), 57-69. Retrieved from https://journal.uny.ac.id/index.php/cp/article/view/9786/pdf. \%0A. 
Rosidah, A. (2016). Penerapan Media Pembelajaran Visual Untuk Meningkatkan Pemahaman Konsep Siswa Pada Mata Pelajaran IPS. Jurnal Cakrawala Pendas, 2(2). https://doi.org/10.31949/jcp.v2i2.499

Safitri. (2020). Pengembangan Media Board Game untuk Pembelajaran Tematik di Sekolah Dasar. Jurnal Inovasi Pembelajaran, 6(2). https://doi.org/https://doi.org/10.22219/jinop.v6i2.8186.

Safitri, R. W., Primiani, C. N., \& Hartini, H. (2018). Pengembangan Media Flashcard Tematik Berbasis Permainan Tradisional Untuk Kelas IV Sub Tema Lingkungan Tempat Tinggalku. Pendidikan Dasar Dan Pembelajaran, 8(1), 11. https://doi.org/http://doi.org/10.25273/pe.v8i1.1332.

Sunismi. (2015). Developing Guided Discovery Learning Materials Using Mathematics Mobile Learning Application As An Alternative Media For The Students Calculus II. Cakrawala Pendidikan, 34(5). https://doi.org/https://doi.org/10.21831/cp.v3i3.7340.

Suyeni, P. W., Wirya, N., \& Ujianti, P. R. (2016). Penerapan Metode Demonstrasi Melalui Permainan Tradisional Magoak-Goakan Untuk Meningkatkan Kemampuan Kerjasama. Jurnal Pendidikan Anak Usia Undiksha, 4(2). https://doi.org/http://dx.doi.org/10.23887/paud.v4i2.7805.

Triastuti, D., Akbar, S., \& Irawan, E. B. (2017). Pengembangan Media Papan Permainan Panjat Pinang. Jurnal Pendidikan: Teori, Penelitian, Dan Pengembangan, 1(2). https://doi.org/https://doi.org/10.17977/jptpp.v2i10.10073.

Yuniarni, Sari, \& Atiq. (2020). Pengembangan Multimedia Interaktif Video Senam Animasi Berbasis Budaya Khas Kalimantan Barat. Jurnal Obsesi : Jurnal Pendidikan Anak Usia Dini, 4(1). https://doi.org/https://doi.org/10.31004/obsesi.v4i1.331.

Yusnia, Y. (2019). Penggunaan Media Video Scribe Dalam Pembelajaran Literasi Sains Untuk Mahasiswa PGPAUD. Cakrawala Dini: Jurnal Pendidikan Anak Usia Dini, 10(1), 71-75. https://doi.org/https://doi.org/10.17509/cd.v10i1.17436. 